\title{
Split Screen Aesthetics in Soviet Animation
}

\author{
Violetta Evallyo \\ Media Art's Department \\ State Institute for Art Students \\ Moscow, Russia \\ E-mail: amaris_evally@mail.ru
}

\begin{abstract}
The essence of the split screen reception is to separate. However, paradoxically, it combines objects and spaces, integrating new ways of cooperation. The split screen can veil the displayed modernity, enhance the decorative and connotational properties of visual matter in animation.
\end{abstract}

Keywords-split sreen; animation; soviet animation; formal techniques; visual arts; visual culture

\section{INTRODUCTION}

There is a large variety of artistic and formal techniques for the combination of single objects in an entire visual text. Perhaps the most common is the linear narrative, but there is another way of forming a director's conception - a split screen can be used.

We need to find a definition of a split screen. The point of this technique is the segmentation of the space into a single frame. As a result, it is divided into two or more inner frames; it is a split frame. The separate story can take place in each parts of the frame and can use it's own space. It's fundamentally different from the space of the another segment. The rhythms of simultaneous coexisting inner frames can also not be equal. It can be observed not only the simultaneous existence of various objects in different environments, but can also be the absolutely synchronous existence of segments repeating each other, multiplying the same "picture" within the whole frame.

The techniques of split-screen is popular in cinema, but, in animation, it's used rarely. In this article, we'll look at the author's animation of the late Soviet period and will try to figure out a general trend of the introduction split screen techniques into the visual narrative. We will analyze the animation works of filmmakers, such as "The History of a Crime" by Fyodor Khitruk and "Contact" by Vladimir Tarasov.

\section{THE HISTORY OF A CRIME (F. KHITRUK, 1962)}

In 1962, Fyodor Khitruk presented to viewers his "The History of a Crime". For the first time, the animation work was more compound than works other directors. Drawing objects were combined with the photo clips and split screen. [1]

"I wrote (or rather, painted) the script and even came up with a name for it: "There is no sleep, no rest". The script was weak, I understood it myself. But the theme of [noise terror] was painful, like a toothache. Then the editors of the studio sent me to the most experienced playwright Mikhail Davydovich Volpin. ... he said: "There is not enough murder here". Professional flair immediately prompted him the right move. A week later I received a completely new script called "The Story of a Crime"! Just like I wanted". [2, p. 158]

This cartoon, so understandable to the viewers of the epoch of megalopolis culture, had reflected the life of the inhabitants of the big city. Fyodor Khitruk had tried to present some other ideas, but the main theme: "In this picture I was attracted by purely formal ideas, which I had been planned while I was an animator ... I wanted to try the techniques of a split screen, in which several events could take place simultaneously in the one frame. [2, p. 159]

The story of the cartoon tells about the kindest accountant, Vasiliy Vasilyevich Mamin, committing an attempt on murder, being driven to insanity with the noise of city life. The narrative is built as an investigation into the causes of the crime. Critic Deena Gauder notes that the conventionality of the image is innovative for those years: "In the frame, there was only what was needed, no extra details (for example, Mamin's room is only a chair and a TV set on a blue background, there are no walls, no floor, no other objects). This is why the frame was particularly expressive. Moreover, the convention was easily mixed with hyperreal: a real movie was shown on the drawn TV, the room of a neighbor, who was deafened by Vasiliy-Vasilich music, consisted only of a huge music center connected to a $\mathrm{TV}$, but this center was not a drawing, but a black and white photograph, like a children's applique whithin a colored background". [3]

The appearance of split screen in the visual text of the "The Story of a crime" made it possible not to short-circuit the hero within a single screen. We can see the life and the space in which the character lives and suffers from "domestic terrorism," as the director himself designated the main line.

In the episode where the protagonist sits in his office, the picture outside the window "comes alive" - there is an active construction. The moving crane and the rapidly growing blocks of the next high-rise building behind the window shown like as autonomous space. Clear geometric boundaries make it a kind of screen reality. We can see that the spatially close reality of the construction is far from the hero, focused on his papers, typewriter and filing cabinet. He is locked up in his world, isolated from everything around 
him, as he is carved with scissors from the general urban bustle.

The director repeatedly emphasizes the paradoxical combination of urban crowding of people, the simultaneity of various activities and, at the same time, autonomy, even the internal isolation of each person or a small human community from the rest of the world. The split screen, which periodically arises when the life of a large house is drawn, accentuates the dramatic nature of coexistence in a single apartment space of different people, who is leading different lives, and engaging in different affairs in different moods. In this case, split screen helps to show the viewer the spatial arrangement of characters living in their segmentapartments and not suspecting the presence of neighbors.

In one of the episodes, the protagonist is moved to the lower right corner. The neighbor, who is idler; the player; and who came home at night to be scandalous with his wife, is in the upper left corner. In this case, they do not intersect in one frame. However, the black space around the "window" with the protagonist denotes a transitional, connecting territory of staircases and other apartments through which all sounds pass freely and reach the habitat of the protagonist.

This creates a way of life of the individual in the emptiness - but with a permanent, aggressive and completely impersonal influence of other inhabitants of the metropolis. Khitruk creates a picture of loneliness and crowding, spatial isolation and permeability, the absence of repressive institutions and the atmosphere of non-directed, and elemental aggressiveness, which itself lives in the urban space. The brightly described psychology of people of the megalopolis, their everyday realities, leading to permanent stress, in which the concepts of ideology, state, politics are lost, raise the film over the historical context. In the book "The profession of the animator" the director himself recalls: "... Sergey Alimov came ... brought his own drawing, executed in a modern style, very tough and sharp. Made a completely different picture of the city, which looked like a conglomerate. The buildings seemed to hang in the air and looked not just an architectural composition, but got a figurative, anthropomorphic characteristic, they became like small worlds. I realized: now the film is getting that detachment from everyday details, the acuteness I was looking for". [2, p.159-160] And this social reality, so subtly emphasized and naked by Khitruk, is painfully familiar to us today.

In the dance episode, split screening enhances the dramatic heat of the situation. The upper part of the screen is replete with movement, but in the lower part - the dark one - only the chandelier is shaking, but this split frame laconically strengthens the image of the tension reigning in the lower "window".

Khitruk did not dwell on the division into two parts, he tried to accommodate the third "window". The guests go home, and another space is added in the upper window - an elevator that fills almost the entire dark part of the screen, which is a kind of connecting link between the stairwells and the segment of apartments, being the point of direct contact between isolated city residents. It is interesting that in another Khitruk's cartoon "Film, film, film", the elevator also becomes a point of contact between the disunited spaces and the employees of the film studio.

Relying on the theory of communications by U. Eco, Fomina V. notes that the multilayeredness and multivariance of perusal is inherent in the scenario of animation models of Khitruk. The components of the film provide a style unity: "These characteristics of fractal sets, similar to the geometry of living systems and memory structures, allow you to repeatedly compress information and concentrate the action. Such structures are immanent to human nature and are most perceptible". [4] This "polyphony of meanings" finds its visual realization in the split screen structure of the cartoon "The Story of a Crime."

From the "technical" point of view, the split screen technique introduced by Khitruk has several specific qualities. The following one after the other split frames move at a fairly moderate pace. New segments are introduced into the story in turn, without overloading the window space. If an active movement begins in one segment, in others it becomes static or minimal. In view of this decision, there is no impression of chaotic flickering of characters and details.

In this case, the split screen performs several other functions: draws a map of the social space of the heroes, at the expense of details helps to more fully draw characters, and allows to smoothly enter other characters simply by "turning on the light" in their apartments.

When analyzing these split screen comparisons, the question arises of the real cause for the psychic breakdown of the hero: was the noise and the impossibility of normal sleep lead to a crisis or his loneliness, obsession with work and the ideal order? Loneliness in the crowd becomes one of the main themes of the cartoon, it emphasizes the disconnectedness of the inhabitants of a metropolis closed in the segments of their apartments.

In the comedic manner, Khitruk shows how mercilessly psychological pressure on an individual is from a human array that is indifferent to individual capabilities and needs. The social system is secretly hostile to a single "screw". This forces the hero to come out in his defense, to become aggressive. "He was with the crowd in the street and deaf from his own scream". [5] But what is the real crime? Is it only those actions that leave material evidence forming the "criminal case"? What about the moral damage to which the personality of a deafened society, the state machine, the metropolis? Maybe it was the real crime that Fyodor Khitruk made into the title of his cartoon?

This work by Khitruk was oriented not only to the adult, but also to the child's perception. In the split screen, "flirting" with windows and frames, not only profound semantic subtexts directed at adult viewers are revealed, but also the entertaining shell of "The History of a Crime". The sad subject, interpreted in an unexpected split screen aesthetics, acquires elements of attraction. The emphasis is shifted to an extravagant form that exactly corresponds to the stated problem - the difficulties of coexistence of very different 
people in the megapolis. As a result, the anesthetization of the problem works to overcome the atmosphere of emotional depression. The cartoon gives even an easy hope of overcoming the circumstances of life. After all, not only did the hero break his shell and go beyond what is permissible, but the society itself was in its position in the face of the noise "terrorist" of the loader, who created such a rumble that the whole apartment building began to shake.

Having in its structure the main nerve such as topical issue, familiar to everyone, "The history of a crime" has become successful not only the viewers, but also among experts in the field of art.

Boyarsky I. noted that in the animated art there was a tendency to move to intellectual films, "philosophical generalization came under the power of drawings and dolls. The ability of animation to flesh out abstract concepts opened up prospects for a figurative philosophy. For a long time our art had strong reputation for "easy genre". Now the animated films set and solve more complex problems". [6]

\section{CONTACT (VladimiR TARASOV, 1978)}

In the 70's of the 20th century, the animation comes to the forefront of human psychology and the emphasis shifts towards internal, personal processes. Krivulya N. Notes that "in the films of the 60's and 70's, the movement from the outside world to the inner space, to the world of consciousness is carried out on the editing principle and optical transformations". [7] Vladimir Tarasov's cartoon "Contact" stands out among other works of animators of those years not only unpopular for the animation of the genre of fantasy, but also for an unusual visual solution such as optical graphics, a split screen composition of the frame.

The story of the cartoon tells us about meeting between the artist and an alien who flew to Earth with an introductory purpose. During the whole cartoon, the alien tries to convince the person, pursuing him and trying to return the artist boots forgotten on the lake shore. In pursuit, the alien makes several stop. To feel the beauty of nature and "penetrate" them, he takes the form of a new object for itself; it can be boots, a butterfly or a bird. The kindness of the newcomer, his friendliness and openness to the new and unknown, that some note of as naivety, can cause a man to forget his fears.

On a wonderful sunny summer day, the artist goes to nature, walking and waving his pencil step-by-step. A bright butterfly attracts the attention of the hero, and he leans over it. The butterfly is enclosed in the lens space and beats against the boundary. The image in this segment of the screen space reminder is the film's negative. The author seems to be trying to show us the opposite side of human nature: we see a pin pierce a butterfly and, dying, it spreads wings, which solidify as a correct but inanimate geometric figure. However, in reality, the artist does not want to harm nature, and, returning to the space of a summer day, the butterfly flies from the palm of the person.

And one more, the "dark", destructive side is contrasted with the bright one: a bird just shown beating in a cage enclosed in a spectacle frame, in reality is sitting quietly on the artist's finger and then flies away. Gloomy scenarios of human interaction with nature remain unfulfilled. But it is important for the director to show awareness of the dark possibilities of human activity, to make it clear what are the contrasting options for people's interaction with the outside world.

In contrast to the two-dimensional vision of a person, the perception of a newcomer has a rather complex geometric structure that is more similar to photography, being a fragmented vision. A visitor from another galaxy, as if looking through the lens of an actual lens, immediately brings the "sight" of his triangular eye to the artist. In this case, the artist himself visually appears on the other side of reality.

With the help of geometric segmentation of the screen space, Tarasov emphasizes the features of the perception of reality by the guest of the Earth. In the triangle of the "eye", the clarity of the image and the brightness of the colors are preserved, and the background is blurred. The colors are clouded. It is noteworthy that such fragmented vision of the alien character Tarasova notes for himself the main thing, the essence of what he saw, focusing only on one object each time. Interesting and attentive work of the director with reflections: in a drop of water, the figure of the artist is serene, but in the reflection of his glasses under frightened eyes, the silhouette of the stranger is calm.

The ability to transform the plastic matter of one's own body, imitation of observable things for the sake of their knowledge is the essence of the alien organism. And the director appropriates this "alien" quality of the screen reality. Thus, the alien seems to present his properties to the earthly world around him.

However, the horror of a possible scenario of events is also growing. The freeze-frame with the frightened face of the artist becomes black and white and is associated with the graphic works of Maurice Escher. The lens segment of the glasses, reflecting the hero's subconscious, grows, visualizing his fears of being in the same cage as is usually reserved for birds. It is noteworthy that the plastic matter of an alien in a "stable" state has a form remotely resembling a cochlea. And in a black and white vision of the artist, a guest from the another planet takes the form of a chthonic octopuslike monster, pulling the strings of puppets — inhabitants of the Earth.

Like the Vertov kino-eye, an alien "photographs" the flight of the artist, but does not despair. His attention shifts to a butterfly, and he imitates its shape, trying to fly himself. Having flown up, he again sees the supposed friend in the person of the artist and takes the form of a person, putting on himself human "attributes": boots, scarf, hat and sketch book of the artist. Unable to express the harmlessness of their intentions in words, the stranger tries to reproduce the musical leitmotif of the cartoon. Only then does everything falls into place; the artist begins to correct the musical structure, and all fears disappear. Earthman and the stranger go hand in hand as good friends and even colleagues. Contact has been completed. 
In addition to the unusual visual split screen structure, the cartoon affirms, unifying the power of music. It is also interesting that both the color palette of "Contact", the fashion image of the artist, and the combination of semantic contexts conjure up associations with the Yellow Submarine clip of The Beatles. In those years, censorship still existed and dictated artists to adhere to strict boundaries, Tarasov himself recalls that "the fantasy was an outlet in our work it was possible to do things that did not pass in other genres and directions, work boldly, come up with some unexpected situations...And then to touch everything that was connected with "The Beatles", it was problematic everywhere, except for fantasy...". [8]

In general, we can conclude that under the mask of the stranger Tarasov concealed a representative of "hostile capitalist countries", whose fear at the state level was implanted by those living behind the iron curtain. The director illustrates the hope that similar people, perhaps more open and kind than ordinary Soviet citizens, live outside the borders of the USSR. And on the eve of the Olympic Games in Moscow in 1980, the prospect of meeting with "aliens" is not so scary. Noting the symbolism, metamorphosis and paradoxical ironic perception of reality and reality, Krivulya N. makes a logical conclusion that "the metaphorical nature of the 70's appears as a means of evading censorship and withdrawal to their individual world, which led to the creation of a complex, allusoric stylistics." [7]

The split screen introduced by Tarasov into the visual structure of the cartoon and in the features of the color composition are in close interaction. The transition to a black-and-white image and vice versa symbolizes the movement between the layers of reality consciousnesssubconsciousness. Split screen frames also have a number of features: when the reality of the inner segment of the composition is included in the narrative, the movement of the main screen reality freezes. In some cases, this "background" is blurred. A frame for a split screen segment is a clear geometric shape, whether it be a spectacle frame or a triangular alien eye.

Boyarsky I. notes that "by drawing an image, the artistanimator creates a symbol equivalent to the writer's word; Using the movement, the artist-animator modifies the symbol, promotes its dynamic reincarnation, which enhances the drama". [6]

A fantastic genre of the cartoon "Contact" fully justifies the visual polysemantic solutions embedded in the narrative. Split screen gave the director a unique opportunity to show the difference in perception of the world by characters and to strengthen semantic overtones by color transitions between segments of "realities".

\section{CONCLUSION}

Noting the tendencies of the author's animation, the researcher concludes that by the middle of 1950's, the style movement of animation has arisen: "This process is largely connected with the increase of interest in the person, his inner world, with the expression of the author's philosophical and aesthetic position in the film's structure. In the early sixties in the Soviet cartoon cinema, a sequential process of updating the figurative and plastic form begins, artists intensively exploit, open new methods of concentrating thought in an image, turn to more modern techniques and materials". [9] One of the technical novelties of the semantic and stylistic construction of the visual text is split screening.

After analyzing all of these cartoon works of authorship, we can conclude that the split screen, having its essence the visual separation of objects and spaces, paradoxically is the point of their semantic unification, comparison and interaction.

The split screen is able to emphasize the importance of mapping the present, even ultra-modern, technical and social progress, the emerging megapolis style of life, the "factory" production of art, and organically combined with folklore, traditional forms. In the "History of a Crime", split screen corresponds with the forms of windows, doors, rectangles of rooms in multi-apartment buildings. In the cartoon "Tarasova", "house" means the inner world of heroes. With the help of split screen aesthetics, he contrasts not only the reality of consciousness-subconsciousness, but he also visualizes the specifics of perception of "one's own" and "others."

In addition, it is obvious that the poly screen in these works enhances the decorative and entertaining properties of visual matter. Due to the "game" of frames and windows, not only is the expansion of semantic connotations is achieved, but the originality of the "picture" is enhanced. It often becomes part of a puzzle in which it can be interesting to understand not only the adult, but also children.

\section{REFERENCES}

[1] Kak poyavilis' pervyye mul'tfil'my. [How did the first cartoons appeared?]. Moscow, Soyuzmul'tproyekt Publ., 2005.

[2] Available at: http://www.fio.vrn.ru/2005/14/first_mult.htm

[3] Khitruk F. Professiya-animator. [Profession-animator]. (V 2 tt., t. 1). Moscow, Gayatri Publ., 2007.

[4] Goder D. Russkaya animatsiya: prodolzheniye sleduyet. [Russian animation: the sequel follows]

[5] Available at: http://www.animator.ru/articles/article.phtml?id=54

[6] Fomina V. A. Dramaturgicheskiye modeli sovremennoy animatsii (na materiale rossiyskogo kukol'nogo kino). [Dramaturgic models of modern animation (on the material of the Russian puppet cinema)]. Diss. Moscow, 2012.

[7] Oruell D. 1984 i esse raznykh let. [1984 and an essay of different years]. Moscow, Izdatel'stvo Progress Publ., 1989.

[8] Available at: http://lib.ru/ORWELL/r1984.txt_with-big-pictures.html

[9] Boyarskiy I. Literaturnyye koLLazhi. [Literary COLLages]. Moscow, 1996.

[10] Available at: http://www.pereplet.ru/text/boyarskiy.html

[11] Krivulya N.G. Osnovnyye tendentsii avtorskoy animatsii Rossii 6090-kh. [The main trends of author's animation of Russia 60-90-s] godov. Diss. Moscow, 2001.

[12] Available at: http://www.dissercat.com/content/osnovnye-tendentsiiavtorskoi-animatsii-rossii-60-90-kh-godov

[13] Tarasov V. Animatsiya ot slova dusha. ["Animation" from the word "soul"] Zhurnal Yesli [The magazine "If"]

[14] Available at: http://www.animator.ru/articles/article.phtml?id=150 
[15] Gorokhova O.V. Kul'turnyy fenomen detskosti v aspekte tvorcheskoy deyatel'nosti. [The cultural phenomenon of childishness in the aspect of creative activity] Diss. Yaroslavl', 2009.

[16] Available at: http://www.dissercat.com/content/kulturnyi-fenomendetskosti-v-aspekte-tvorcheskoi-deyatelnosti 